Administrative Issues Journal: Connecting Education, Practice, and Research, Winter 2019

Vol. 9, No. 2: 28-41. DOI: 10.5929/9.2.4

\title{
Tenure clock policy transparency for biological clock (family friendly) events
}

\author{
Michelle McEacharn, D.B.A. \\ Katherine Boswell, Ph.D. \\ Kriti Chauhan, Ph.D. \\ Sarah O. Siereveld, B.F.A. \\ University of Louisiana Monroe
}

\begin{abstract}
The intention of this study is to investigate the transparency of information on university websites regarding the policies in place related to leave and/or tenure clock extensions for child-related events such as childbirth, adoption, or placement of a foster child. The main purpose is to improve awareness about the policies existing in academia related to these events. The secondary purpose is to determine whether major institutional characteristics affect the family-friendly policies of these institutions. Nearly $80 \%$ of the institutions studied communicated some type of information on their website related to tenure clock extension policies. An analysis of the data from these colleges/universities is provided so that other institutions who are developing or reviewing their own policies are aware of the typical policies provided by other institutions. The study found significant differences in policy availability and attributes based on major institutional characteristics.
\end{abstract}

Keywords: Policies, Work-Life Balance, Tenure, Transparency, Family Leave, Family-Friendly Policies

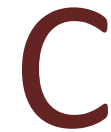

onsider two independent situations that led to curiosity, then motivation, for this study. In the first scenario, two unrelated tenure-track faculty members in the same department at a university awaited the birth of a child during the first few weeks of September. One faculty member was male; the other was female. The male faculty member lost a couple of days of work during the week of the child's birth but, otherwise, the male's work life was relatively unaffected by the birth. However, due to the timing of the birth in the semester, the female faculty member took a semester of unpaid leave. The female faculty member lost a large portion of the productivity for that semester towards meeting the requirements for tenure. Neither faculty member sought consequent relief in the expectations for tenure, nor was it granted. The reason for seeking no relief is unknown. One possible justification is that no relief was deemed necessary. However, another equally possible scenario may have been that the affected faculty members or others in the chain of command were unaware that such an option existed.

In the second scenario, at the same university, a potential female faculty candidate was on-campus for an interview. During the interview, the candidate questioned whether any relief in her tenure clock would be awarded if she were to have a child during her probationary period for tenure. The search committee

MCEACHARN, BOSWELL, CHAUHAN, \& SIEREVELD / DOI: 10.5929/9.2.4 
was not aware of any written policy or prior precedence related to tenure-clock extensions for childbirth. Further investigation indicated that such relief was available by request of the faculty member and with approval of the Chair and Dean for that faculty member. Had the transparency and communication of the policy been improved, the search committee could have responded to the inquiry by the prospective faculty member in a timelier manner. Also, the unfamiliarity of the policy could have been a driving force behind the faculty members in the first example not seeking such relief, an option that likely could have helped the female faculty member considerably.

\section{Purpose}

The intention of this study is to investigate the transparency of information on university websites regarding the policies in place related to leave and/or tenure clock extensions for child-related events such as childbirth, adoption, or placement of a foster child. The primary purpose is to improve awareness about the policies in place related to these events, and to provide suggestions to streamline policy information around the tenure clock. The secondary purpose is to determine whether major institutional characteristics affect the family-related policies offered by higher education organizations.

\section{Background and Previous Research}

While the policies that may (or may not) exist within academic institutions would apply across all disciplines, faculty within the business disciplines may find the existence of such family-friendly policies to have more significance. Many of the business disciplines, such as accounting and finance, are facing extreme shortages in available terminally-qualified candidates (Plumlee \& Reckers, 2014). Several measures are being developed to attract and retain faculty (Boyle, Carpenter, \& Hermanson, 2014; Hunt \& Jones, 2015; Fish, Becker, \& Miller, 2017). The ready availability of family-friendly policies for childrelated events could certainly serve as an advantage in the recruiting market. Additionally, females are representing a larger percentage of new doctorates. AACSB - International reported almost $40 \%$ of new doctorates in 2014-2015 were female (The Association to Advance Collegiate Schools of Business, 2015). The American Institute of Certified Public Accountants reported 50\% of accounting masters awarded in 2016-2017 were awarded to female candidates (AICPA, 2017). The percentage of female research doctorates among FT faculty has increased by 3.1\% from 2012-2017 (AICPA 2017). The trend appears to indicate a continued growth of female faculty members in the future, which will likely drive a greater need for transparency of family-friendly faculty policies.

A significant push toward family-friendly policies, and specifically, tenure extension options for childrelated events occurred in November 2001, when the American Association of University Professors produced a "Statement of Principles on Family Responsibilities and Academic Work." Another key study occurred in 2005 by the University of Michigan's Center for Education of Women which published results on the family-friendly policies existing in higher education. The policies under study included tenure clock extensions and leave requirements in conjunction with the Family and Medical Leave Act (FMLA) of 1993. The study also looked at other family-friendly policies, such as a reduction in job duty expectations, paid dependent care, part-time work options and employment assistance for spouses/partners. In this 2005 study, research institutions, where women faculty are less likely to be employed, were found to provide nearly double the family-friendly options of its counterpart institutions. Interestingly, men have been found to benefit more than women from work-life policies, such as on-site childcare, in gaining academic rank at US PhD-granting economics departments (Juraqulova, McCluskey, \& Mittelhammer, 2019). More pertinently, adoption of gender-neutral tenure clock stopping policies is found to reduce female tenure rates and increase male tenure rates at research-intensive economics departments in the US (Antecol, Bedard, \& Stearns, 2018). The discussion paper conjectures that these policies allow men to use the additional time towards their research productivity, which women use for caregiving, thus raising the bar

MCEACHARN, BOSWELL, CHAUHAN, \& SIEREVELD / DOI: 10.5929/9.2.4 
for tenure, leading to underrepresentation of women at higher ranks at that institution. This may possibly be a contributing factor to the finding that female associate professors of accounting at doctoral-granting institutions have a lower publication rate than men (Jordan, Clark, \& Vann, 2008).

While gender-neutral policies may directly benefit men, policies that benefit women can provide reduced social stigma if available to men, thus making it more acceptable for women to take advantage of them (Lazear \& Rosen, 1990; Dahl, Løken, \& Mogstad, 2014). This is of particular importance as the use of familyfriendly policies is still sometimes viewed as potentially detrimental to the candidate during promotion and tenure (June, 2014). Institutionalization and normalization of the use of these policies will help ameliorate this issue (June, 2014). A family event, such as childbirth, negatively affects research productivity over the next few months, and not just a few weeks. Short family leave programs do not adequately account for this productivity decline, which has the potential to negatively affect tenure decisions made at the end of a fixed duration. This makes tenure clock stopping policies useful since one isn't required to take time off, but simply gets to put off the tenure decision for a period of time, usually one year (Antecol, Bedard, \& Stearns, 2018). Thus, family-friendly policies continue to be essential to recruitment and retention, especially of female faculty (Samble, 2008; Lester \& Bers, 2011; Martinez, O’Brien, \& Hebl, 2017).

A key addition to the literature with this current study is an indication as to the transparency of information regarding family-friendly policies specifically related to tenure clock extensions for childrelated events. In The Chronicle of Higher Education, Williams (2002) argued that an institution has both an ethical and legal responsibility to ensure that department chairs, promotion and tenure committees, and external reviewers are aware of the parental leave and tenure clock extensions used by faculty and the impact of that use on tenure and promotion expectations. Quinn, Lange, and Olswang (2004) argued that the details and importance of family-friendly policies must be communicated openly and consistently to all faculty and administrators so that the policies become routine and are viewed as legitimate. However, awareness and implementation of family leave policies have been lacking in academic medicine (Gunn, Freund, Kaplan, Raj, \& Carr, 2014), STEM departments (Su \& Bozeman, 2016) across the US, and biomedical sciences at UC Davis (Villablanca, Beckett, Nettiksimmons, \& Howell, 2011). These studies encourage institutions to develop methods for reminding tenure review committees of the details of relevant family-friendly policies.

The availability of family-friendly policies through simple website searches should provide insight into the transparency of information about a university's child-related family policies. Additionally, since potential faculty candidates will often spend time researching an institution prior to submitting an application or accepting an on-campus site visit invitation, the availability of information on a university's website could make a difference in both the quantity and quality of faculty applications received. Easy online availability or transparency could also indicate institution support and normalization for using family-friendly policies (Kirby \& Krone, 2002; Baxter \& Chesters, 2011). However, while reasonable, more research needs to be undertaken to empirically test these assumptions. Still, we believe the results of this study will be valuable to universities in ensuring they have policies that are available and competitive with other higher education institutions.

\section{Study Method}

As of the beginning of 2019, there were 189 colleges/universities accredited in both business and accounting by $A A C S B$ - International. These institutions were selected because they represent institutions with a focus on continuous quality improvement as evidenced by their ongoing maintenance of accreditation activities for their business schools. These institutions would also represent a broad spectrum of universities across the country. Additionally, those institutions participating in such

MCEACHARN, BOSWELL, CHAUHAN, \& SIEREVELD / DOI: 10.5929/9.2.4 
accreditation maintenance activities likely face more pressure in the recruiting and retention of academically-qualified faculty. Plus, many of the disciplines (e.g., accounting and finance) under AACSBInternational face significant faculty recruitment demands. From this group of 189 institutions, only those colleges/universities located in the United States were selected for the study. This selection was made to reduce any complexity that may arise from the legal and structural nature of those organizations located outside the United States. As a result, there were a total of 175 institutions remaining for the study.

From this study group, 131 schools (75\%) represented publicly funded institutions with the remaining 44 schools (25\%) listed as privately-funded institutions. A review of the Carnegie Classification for the group was performed. The Carnegie Classification was not available for 21 institutions, resulting in a sub-sample of 154 schools. Of those, half represented Doctoral/Research - Extensive; the remainder of the group was evenly split between Doctoral/Research - Intensive (24\%) and Master's I (26\%) status. For regional classification, the American Accounting Association breakdown of regions was used to classify these institutions. Based on these regional classifications, the breakdown of sample institutions in each region of the United States was as follows: Northeast, 8.6\%; Mid-Atlantic, 10.3\%; Southeast, 26.9\%; Ohio, 5.1\%; Midwest, 20.6\%; Southwest, 14.9\%; and Western, 13.7\%. To avoid the complications from the small sample size for the Ohio region, we combined Ohio with the Midwest region.

To conduct the study, a search of the websites for each university was performed. The search centered on identifiable policies related to tenure clock extensions for family-related events such as birth, adoption, or placement of a foster child. These policies were generally found to exist in the Faculty \& Staff portion of each website. Faculty Handbooks, Collective Bargaining Agreements, or Provost/Academic Affairs links represented the greatest source of data. In addition to searches within these major sections of each website, a general search of key terms was also conducted on each website. Examples of key terms include: family leave, parental leave, maternity leave, tenure clock, extension of tenure probationary period, tenure stoppage, tenure extensions, probationary exceptions, etc.

The information was then analyzed for key characteristics before it was categorized appropriately. The characteristics of family-friendly tenure clock policies centered on five key items of information: (1) Tenure Clock Mention, (2) Tenure Clock Extension Description, (3) Tenure Clock Extension Characteristics, (4) Other Related Information, and (5) No Policy Found. Each of the first four items is discussed in more detail in the following paragraphs.

First, for Tenure Clock Mention, the website information was reviewed for any mention of tenure clock stoppage or probationary period extension. This item was noted as positive if any information related to such policies was found on the website. For this item, even a mention on the website that "No extensions of the probationary period for tenure are available" was coded as a positive response since information about such policies is being communicated. A negative response was coded for any institution in which no information related to tenure clock policy, tenure stoppages, probationary period extensions, etc. could be found on the website.

The second item of information, Tenure Clock Extension Description, reviewed on each website was of critical significance to the study. This information centered on the actual description of any tenure clock extension policies that were found to exist on the websites. This was the most difficult item to analyze as there was extensive diversity in wording, depth of information provided, and established tone of the policy. After an intense review of the descriptions, and to help us and readers understand the information that was found in the policies, we devised a four-category classification schema for the data: Automatic (extension is granted automatically for child-related events such as birth or adoption), By Request with Automatic Approval (extension is automatically approved once requested in writing), By Request (extension can be requested for such events, but must go through an approval process), and

MCEACHARN, BOSWELL, CHAUHAN, \& SIEREVELD / DOI: 10.5929/9.2.4 
Unknown/Unavailable/Undeterminable (information is extremely vague or somewhat "iffy," mention is made but no information is easily available, or no policy can be determined to exist).

The four-category classification of the website descriptions could be called into question as arbitrary and/or open to interpretation by others. Every attempt was made to keep the classification process as objective as possible. First, specific criteria and key terms were used in the classification process. Second, unless deemed exceptional, descriptions that referenced family-related events were classed into the most family-friendly classification appropriate for the description (e.g., classed as By Request instead of Unknown). Third, items that were particularly difficult to classify were discussed more thoroughly and a decision was made as to appropriate classification.

Some examples of the types of descriptions found and the resulting classifications are shown in Table 1 below.

Table 1

Tenure Clock Extension Policies Classification Examples

\begin{tabular}{|c|c|c|}
\hline Classification & Description & University \\
\hline Automatic & $\begin{array}{l}\text { The probationary period will be extended automatically one } \\
\text { year for the parent, male or female, upon the birth or adoption } \\
\text { of a child occurring on or before May } 21 \text { of the academic year } \\
\text { preceding the year in which the tenure decision is to be made. }\end{array}$ & $\begin{array}{l}\text { Villanova } \\
\text { University }\end{array}$ \\
\hline & probationary & \\
\hline $\begin{array}{l}\text { By Request } \\
\quad \text { with } \\
\text { Automatic } \\
\text { Approval }\end{array}$ & $\begin{array}{l}\text { is automatically granted to either parent (or both, if both } \\
\text { parents are tenure-track faculty members) in recognition of the } \\
\text { demands of caring for a newborn child or a child under five } \\
\text { newly placed for adoption or foster care. The request should be } \\
\text { made within a year of the child's arrival in the family }\end{array}$ & $\begin{array}{l}\text { Virginia } \\
\text { Polytechnic } \\
\text { Institute }\end{array}$ \\
\hline $\begin{array}{c}\text { By Request } \\
\text { with Approval }\end{array}$ & $\begin{array}{l}\text { A one-year extension of the probationary period will be granted } \\
\text { by the Provost upon request of a probationary faculty member } \\
\text { who (1) has or shares primary responsibility for the care of an } \\
\text { infant or a newly-adopted child under age five, and who must } \\
\text { commit substantial portions of time to this care }\end{array}$ & $\begin{array}{l}\text { Miami } \\
\text { University }\end{array}$ \\
\hline $\begin{array}{l}\text { Unknown or } \\
\text { Unavailable }\end{array}$ & $\begin{array}{l}\text { At the request of a candidate and upon the advice of a } \\
\text { candidate's department chair, college dean, and the Provost, } \\
\text { the President may defer the tenure recommendation to the } \\
\text { seventh ( } 7 \text { th) year of employment or later. }\end{array}$ & $\begin{array}{l}\text { University of } \\
\text { Southern } \\
\text { Mississippi }\end{array}$ \\
\hline
\end{tabular}

The third area of data analysis centered on Tenure Clock Extension Characteristics. This analysis focused on such items as the typical length of the extension, limitations related to the extension, etc. The fourth area of analysis, Other Related Items, was a catch-all category for any other tenure clock extension information found on the website but not specific to the other categories of interest. In general, there were very few items coded into this category. The category included items that needed "login access" to 
gain more information to policies or wording such as "Work accomplished during the extension period may be counted toward the tenure package." These items will be discussed later.

\section{Results}

The major motivation for this study was to discover the extent to which tenure clock extension policies for child-related events were readily available in university communications. For those with transparent policies an additional motivation was to analyze the specific details of the policies. The data should prove to be of interest to many university faculty. Additionally, for those involved in university governance and policy development (i.e., holding administrative roles, serving as a faculty senator, etc.), the data provides evidence on the availability of such options at other universities and the type of policies and constraints/limitations that are in place.

As to the first item of consideration (Tenure Clock Mention), about $86 \%$ (150 out of 175) of the institutions disclosed some information related to tenure clock extensions on their websites; mention of tenure clock extensions could not be found on 25 websites. All of the policies we found appeared to be gender-neutral. We found no clear and direct policies that applied only to female faculty. There was no clear indication that even policies related specifically to pregnancy applied only to female faculty. The policies generally referred to family events, such as pregnancy and adoption, and were/are applicable to both female and male faculty. As to the classification of the data in the four categories for Tenure Clock Description, Table 2 below is presented as a summary.

Table 2

Summary of Tenure Clock Description Classifications

\begin{tabular}{|c|c|c|}
\hline Classification & Number & Percentage \\
\hline Automatic Extension & 13 & $7.4 \%$ \\
\hline Automatic Extension with Request & 19 & $10.9 \%$ \\
\hline Extension Available with Request and Approval & 118 & $67.4 \%$ \\
\hline Unclear/Vague Extension Policy & 11 & $6.3 \%$ \\
\hline No Policy Found & 14 & $8.0 \%$ \\
\hline Total & 175 & $100 \%$ \\
\hline
\end{tabular}

For the third item of interest (Tenure Clock Extension Characteristics), a review of the tenure extension approval process was analyzed for all institutions that reported some tenure clock extension information. Of this total, the 26 institutions that did not include any tenure clock extension information on their website or needed login information were excluded from the analysis; a total of 150 institutions were reviewed for tenure extension approval information. From this group of 150 institutions, over 20\% (34 institutions representing $22.7 \%$ of the total) of the group did not provide detailed clear data as to limitations (e.g., length of the extension, the maximum length of the extension, etc.). The majority (113 institutions or $75.3 \%$ ) of the institutions provided an opportunity for one-year extensions in the tenure clock for family-related events. Note that sometimes the one year is automatic; sometimes the one year is dependent upon request and approval. More statistics regarding that breakdown will be presented

MCEACHARN, BOSWELL, CHAUHAN, \& SIEREVELD / DOI: 10.5929/9.2.4 
later. Over $10 \%$ (17 institutions representing $11.3 \%$ ) of the group indicates that the tenure clock extension is tied to whether the faculty member takes leave for the event. In this case, a faculty member who does not take leave for the family event would not be eligible for a tenure clock extension. Table 3 provides more detailed information specific to Tenure Clock Characteristics in relation to Tenure Clock Description categories.

Table 3

Tenure Clock Characteristics by Tenure Clock Descriptive Categories (Actual Number of Institutions with Percentage in Parenthesis)

\begin{tabular}{lccccc}
\hline $\begin{array}{l}\text { Tenure Clock } \\
\text { Descriptive } \\
\text { Category }\end{array}$ & $\begin{array}{c}\text { One Year } \\
\text { Extension }\end{array}$ & $\begin{array}{c}\text { Extension } \\
\text { Based on } \\
\text { Leave }\end{array}$ & $\begin{array}{c}\text { Extension }> \\
\text { one year }\end{array}$ & $\begin{array}{c}\text { Unclear or } \\
\text { Vague }\end{array}$ & Total \\
\hline $\begin{array}{l}\text { Automatic } \\
\text { Extension }\end{array}$ & $4(30.8 \%)$ & $3(23.1 \%)$ & $0(0 \%)$ & $6(46.2 \%)$ & 13 \\
$\begin{array}{l}\text { Automatic } \\
\text { Extension with } \\
\text { Request }\end{array}$ & $7(36.8 \%)$ & $3(15.8 \%)$ & $0(0 \%)$ & $9(47.4 \%)$ & 19 \\
$\begin{array}{l}\text { Extension } \\
\text { Available with } \\
\text { Request and } \\
\text { Approval }\end{array}$ & $85(72.0 \%)$ & $11(9.3 \%)$ & $3(2.5 \%)$ & $19(16.1 \%)$ & 118 \\
\multicolumn{1}{c}{ Total } & $96(64 \%)$ & $17(11.3 \%)$ & $3(2 \%)$ & $34(22.7 \%)$ & 150 \\
\hline
\end{tabular}

Further analysis revealed that nearly $40 \%$ (59 institutions or $39.3 \%$ ) disclosed a maximum extension length to the tenure clock extension. The majority reported a maximum possible extension of two years. This limit was reported by 56 (37.3\%) of the institutions that disclosed tenure clock information. Three (2\%) of the institutions reported a maximum tenure clock extension of three years. While $57(38 \%)$ of the institutions indicated that a one-year extension was available or could be available, only nine $(6.0 \%)$ reported an extension limit of only one year. For those reporting a two-year maximum extension, five of those were reported by schools with automatic extensions and five of those were reported by schools with automatic approvals on request. The remaining 46 institutions applied to schools that reported extensions were available by request. For the institutions reporting a one-year maximum extension, all of these were disclosed by schools that reported extensions available by request. For the three institutions reporting a maximum extension of three years, two of those were schools that granted extensions by request and one was a school that automatically approves requests for the extension. Additionally, it should be noted that 98 of the institutions, representing 65.3\%, required provost/president/chancellor approval for tenure extensions. Only $21(14 \%)$ institutions noted that approval could be granted by a department chair or dean for an extension of the tenure clock for family-related events.

Other requirements and constraints for tenure clock extensions include specifics such as when the extension is possible, when it can be requested, etc. These are, of course, not consistent over the various universities. Some examples are shown in Table 4. These examples provide items that should likely be considered when developing thorough and transparent policies.

MCEACHARN, BOSWELL, CHAUHAN, \& SIEREVELD / DOI: 10.5929/9.2.4 
Table 4

Other Relevant Information Examples

\begin{tabular}{|c|c|}
\hline Institution Name & Tenure Clock Policy Items \\
\hline University of Northern Colorado & Request must be made 3 months prior to event. \\
\hline Rider University & Request must be made within 6 months of event. \\
\hline University of Notre Dame & $\begin{array}{l}\text { Request must be made } 6 \text { months prior to or after } \\
\text { event. }\end{array}$ \\
\hline Auburn University & $\begin{array}{l}\text { Request must be made within one year after event, } \\
\text { but within first five years of service. }\end{array}$ \\
\hline Ball State University & Extensions possible after one year of service. \\
\hline $\begin{array}{l}\text { Baruch College, College of Charleston, and } \\
\text { Louisiana Tech University }\end{array}$ & Request must be made within 90 days of event. \\
\hline Oregon State University & $\begin{array}{l}\text { Request must be made before } 6 / 1 \text { of year prior to } \\
\text { tenure review. }\end{array}$ \\
\hline University of Kansas & Request must occur before $5 / 1$ of tenure year. \\
\hline University of North Texas & $\begin{array}{l}\text { Extension must occur before fourth year of tenure } \\
\text { clock. }\end{array}$ \\
\hline Wright State University & $\begin{array}{l}\text { Extension must occur before } 3^{\text {rd }} \text { year of tenure clock, } \\
\text { or up to the } 5^{\text {th }} \text { year of tenure clock if progress shows } \\
\text { being on-track. }\end{array}$ \\
\hline
\end{tabular}

While the availability of a family-friendly policy appears to exist among many higher education institutions, the ease of access to those policies is critical toward recruiting new faculty and ensuring transparency internally for both those seeking tenure and promotion, as well as, the committees evaluating those individuals. Thus, we analyzed the university websites for the location where the policies related to tenure clock extension for family events were found. We identified five locations for tenureclock extension policies and categorized them as Faculty Handbook/Bylaws, Academic Affairs Policies, Human Resource Policies and Collective Bargaining Agreements, and Other Website Locations. We relied upon the most extensive tenure clock policy information found on the website. There were rarely, if ever, multiple website locations where such information was found.

Of those 150 institutions where policies could be found, it was encouraging that just over $75 \%$ (113 institutions) communicated their policies through "expected" routes. Over 40\% (64 institutions representing $42.7 \%$ ) communicated their policies through various academic policies as found through academic affairs web links. About one third (32.7\%) communicated these family-related tenure extension policies through the Faculty Handbook/Bylaws, with the majority of these policies communicated under the Promotion and Tenure section of the Handbook/Bylaws. A small few (6 institutions or 4\%) presented

MCEACHARN, BOSWELL, CHAUHAN, \& SIEREVELD / DOI: 10.5929/9.2.4 
the policy in a collective bargaining agreement. Just over 13\% (20 institutions) maintained these policies under human resource links. For those faculty unaware of unionized institutions, finding family-related policies in collective bargaining agreements would not be expected. For $4 \%$ of the institutions, collective bargaining agreements was where these policies were found. However, for just over $7 \%$ of the universities, the mention of tenure clock extensions for family-related events was found in other website locations. In this case, the information was found by web search through key terms and found in obscure areas of the websites. In at least one case, a password was necessary to gain access to such policies. An analysis was also conducted with respect to how friendly the policy was as compared to its location on the university's website. Table 5 presents the information gained from this analysis.

Table 5

Tenure Clock Policy Availability by Tenure Clock Descriptive Categories (Actual Number of Institutions with Percentage in Parenthesis)

\begin{tabular}{lcccccc}
\hline $\begin{array}{l}\text { Tenure Clock } \\
\text { Descriptive } \\
\text { Category }\end{array}$ & $\begin{array}{c}\text { Faculty } \\
\text { Handbook }\end{array}$ & $\begin{array}{c}\text { Academic } \\
\text { Policy }\end{array}$ & $\begin{array}{c}\text { Human } \\
\text { Resource } \\
\text { Policy }\end{array}$ & $\begin{array}{c}\text { Collective } \\
\text { Bargaining } \\
\text { Agreement }\end{array}$ & $\begin{array}{c}\text { Other } \\
\text { Website } \\
\text { Location }\end{array}$ & Total \\
\hline $\begin{array}{l}\text { Automatic } \\
\text { Extension }\end{array}$ & $6(46.2 \%)$ & $2(15.4 \%)$ & $3(23.1 \%)$ & $0(0 \%)$ & $2(15.4 \%)$ & 13 \\
$\begin{array}{l}\text { Automatic } \\
\text { Extension with }\end{array}$ & $7(36.8 \%)$ & $7(36.8 \%)$ & $3(15.8 \%)$ & $0(0 \%)$ & $2(10.5 \%)$ & 19 \\
$\begin{array}{l}\text { Request } \\
\text { Extension }\end{array}$ & & & & & & \\
$\begin{array}{l}\text { Available with } \\
\text { Request and } \\
\text { Approval }\end{array}$ & $36(30.5 \%)$ & $55(46.6 \%)$ & $14(11.9 \%)$ & $6(5.1 \%)$ & $7(5.9 \%)$ & 118 \\
\multicolumn{1}{c}{ Total } & $49(32.7 \%)$ & $64(42.7 \%)$ & $20(13.3 \%)$ & $6(4 \%)$ & $11(7.3 \%)$ & 150 \\
\hline
\end{tabular}

The data in Table 5 does not show any clear and direct link between where the tenure extension policy is located on a university's website and the leniency of the institution with respect to the policy. For example, for those institutions that provide automatic extensions for family-related situations, $46.2 \%$ of the schools had policies in a logical location: the faculty handbook. We identify the most transparent to least transparent locations as follows: faculty handbook, academic affairs, human resources, and then "other." Yet, 38.5\% of the schools with automatic extensions did not have the policy located in a "transparent" location such as the faculty handbook or under academic affairs policies. For those schools that indicate a request may be made for tenure clock extension, just over $60 \%$ of those policies were in transparent locations on the website, either in the faculty handbook or under academic affairs policies. Still, the search for the policy was more extensive for $26.3 \%$ of these schools. For schools with policies that indicated the individual must request and obtain approval for an extension, the data shows that the policy is more likely to be housed under academic affairs policies (46.6\%), but is also often found under the faculty handbook (30.5\%). More extensive searching was only necessary for $22.9 \%$ of those schools to find the family-related tenure extension policies. Overall, while the data analysis indicates that a

MCEACHARN, BOSWELL, CHAUHAN, \& SIEREVELD / DOI: 10.5929/9.2.4 
substantial portion of the schools have extension policies available for family-related events, it seems that the transparency of the information still lags as there are significant percentages of schools that do not have the policy in an easily found location.

\section{Differences by Institutional Characteristics}

A secondary motivation for this study was to determine whether major institutional characteristics influence the "friendliness" of tenure clock extensions for family-related events. Table 6 provides further analysis as to the breakdown of tenure exception decisions by institutional region, institutional control, and Carnegie classification.

Table 6

Tenure Clock Policy by Institutional Characteristics (Actual Number of Institutions with Percentage in Parenthesis)

\begin{tabular}{|c|c|c|c|c|c|}
\hline & Automatic & $\begin{array}{c}\text { By Request w/ } \\
\text { automatic } \\
\text { approval }\end{array}$ & $\begin{array}{l}\text { By request w/ } \\
\text { approval }\end{array}$ & $\begin{array}{l}\text { Unknown or } \\
\text { Unavailable }\end{array}$ & Total \\
\hline \multicolumn{6}{|l|}{ By Region: } \\
\hline Northeast & $5(33.3 \%)$ & $3(20 \%)$ & $4(26.7 \%)$ & $3(20 \%)$ & 15 (8.6\%) \\
\hline Mid-Atlantic & $2(11.1 \%)$ & $4(22.2 \%)$ & $10(55.6 \%)$ & 2 (11.1\%) & $18(10.3 \%)$ \\
\hline Southeast & $2(4.3 \%)$ & $5(10.6 \%)$ & $33(70.2 \%)$ & 7 (14.9\%) & $47(26.9 \%)$ \\
\hline Midwest & $2(4.4 \%)$ & $4(8.9 \%)$ & 35 (77.8\%) & $4(8.9 \%)$ & $45(25.7 \%)$ \\
\hline Southwest & $1(3.8 \%)$ & $2(7.7 \%)$ & 19 (73.1\%) & $4(15.4 \%)$ & $26(14.9 \%)$ \\
\hline Western & $1(4.2 \%)$ & $1(4.2 \%)$ & $17(70.8 \%)$ & $5(20.8 \%)$ & $24(13.7 \%)$ \\
\hline Total & 13 & 19 & 118 & 25 & 175 \\
\hline \multicolumn{6}{|c|}{ By Institutional Control: } \\
\hline Private & $6(13.6 \%)$ & $5(11.4 \%)$ & $22(50 \%)$ & $11(25 \%)$ & $44(25.1 \%)$ \\
\hline Public & $7(5.3 \%)$ & $14(10.7 \%)$ & $96(73.3 \%)$ & $14(10.7 \%)$ & $131(74.9 \%)$ \\
\hline Total & 13 & 19 & 118 & 25 & 175 \\
\hline \multicolumn{6}{|c|}{ By Carnegie Class: } \\
\hline Res- Ext & $7(9.1 \%)$ & $13(16.9 \%)$ & $54(70.1 \%)$ & $3(3.9 \%)$ & 77 (50\%) \\
\hline Res- Int & $5(13.5 \%)$ & $2(5.4 \%)$ & $25(67.6 \%)$ & $5(13.5 \%)$ & 37 (24\%) \\
\hline Master's I & $2(5 \%)$ & $2(5 \%)$ & $22(55 \%)$ & $14(35 \%)$ & 40 (26\%) \\
\hline Total & 14 & 17 & 101 & 22 & 154 \\
\hline
\end{tabular}

Chi-square analysis indicated a statistically significant difference ( $p$-value $<.0001)$ in website information (1) across the regions, (2) between public and private universities, and (3) among the Carnegie classifications.

A general review of Table 6 provides some interesting information. As to regional classification, the eastern seaboard of the United States (Northeast, Mid-Atlantic, and Southeast) made up about half $(45.7 \%)$ of the institutions in the study. The Northeast and Mid-Atlantic regions of the U.S. have the friendliest policies for tenure extension due to family-related events. Over $50 \%$ of the schools in the Northeast region provide for either automatic extensions or automatic extensions upon request; onethird of the schools in the Mid-Atlantic region provide these same family/faculty-friendly policies. The Midwest and the Southeast region were the $2^{\text {nd }}$ friendliest regions with nearly $15 \%$ (14.9\% for the 
Southeast and $13.3 \%$ for the Midwest) having such policies. The Southwest region only had a little over $10 \%$ of their schools with the friendliest (Automatic or Automatic Upon Request) of policies; less than $10 \%$ of the schools in the Western region had the friendliest of policies (Automatic and Automatic upon Request). Regardless, there were still a significant number of institutions in a couple of the regions (Northeast, 20\% and Western, 20.8\%) in which no tenure extension options appeared to be available on the institutions' websites. The Mid-Atlantic and Midwest regions and the southern regions (Southeast and Southwest) were more likely to have some policy information available on their websites than the Northeast and Western regions, with $85 \%$ or more of the institutions in these regions reporting tenure clock extension policies for family-related events on their websites. The institutions in these regions could have an advantage with faculty or prospective faculty interested in the family-friendly policies of an educational institution due to their ease in finding the policies on the university's websites. For those performing a more intensive search for the friendliest policy, the Northeast and Mid-Atlantic regions would have the advantage.

With respect to institutional classification, private institutions made up about $25 \%$ of this study and public institutions made up the remaining $75 \%$. Private institutions were more likely to have the friendliest policies, with $25 \%$ of the schools classified as providing automatic extensions or automatic upon request extensions. Yet, a fourth of these institutions provided no mention of tenure clock extension for family events on their websites. Public institutions, on the other hand, had nearly $90 \%$ (89.3\%) reporting tenure clock extension options for family events, but only $16 \%$ of those institutions provided the friendliest policy options.

The results may not be totally surprising. Private institutions tend to have more discretion in the establishment of policies since they do not face the same political and/or regulatory environment as public institutions. It is also true that private institutions may have the financial resources necessary to attract quality faculty even without the additional attractive family-friendly options. Public institutions, on the other hand, are under the public eye, especially as related to their state/local political environment. Consequently, it may be expected that such institutions would face greater pressure from the public to provide family-friendly options. Public institutions are also more likely bound by financial constraints and, as a result, face greater obstacles in recruiting faculty. Tenure clock extensions for child-related events could certainly prove to be a strong recruiting benefit for these institutions.

The data was analyzed to also determine whether differences existed by Carnegie classification. The Carnegie classification was not available for 21 institutions. Of the remaining 154 institutions, $50 \%$ of those institutions were in the Research-Extensive classification; about $25 \%$ of the institutions fell into the Research-Intensive and Master's I classifications. Analysis of the data by Carnegie classification shows that $96 \%$ of the institutions in the Research-Extensive category had tenure extension policies in place for family-related events available on their websites. Just over $25 \%$ of these institutions provided the friendliest (Automatic or Automatic upon Request) of policies; $70 \%$ of the Research-Extensive institutions indicated that an extension is available upon request and with approval. Less than $4 \%$ did not have a policy found on their website. As to Carnegie classification, Research-Extensive schools proved to be the strongest in terms of support for such policies. These universities most likely represent very large institutions with significantly more resources, in terms of both financial resources and people resources, than other institutions. In some respects, these institutions are perhaps less likely to need such policies to attract faculty. On the other hand, these institutions are so research-driven that some compensation must be allowed for family events that may distract from the research agenda even for brief periods of time.

MCEACHARN, BOSWELL, CHAUHAN, \& SIEREVELD / DOI: 10.5929/9.2.4 
Perhaps of greater interest is the data from the Master's I institutions. These schools could be considered the least friendly. Over one third (35\%) of these institutions did not have tenure extension policies found in our study of their websites. Only $10 \%$ of that group had the friendliest policies. Master's I institutions tend to be smaller in nature and more constrained with respect to resources. Additionally, these institutions were more likely to be thought of as teaching institutions, where family and work-life balance considerations may be deemed by the faculty to be more important than in some Research-Extensive institutions. So, an argument can be made that these institutions are more likely to need these types of family-friendly policies in order to recruit more competitively in the marketplace. Thus, these results are surprising. For Research-Intensive institutions, about $87 \%$ reported tenure clock extension policies for family events, with about $19 \%$ reporting the friendliest policies available to their faculty.

\section{Limitations and Future Research Directions}

There are limitations associated with any descriptive study in which data is gathered solely through website searches. Specific links or pages may be unavailable at the time in which the search is conducted so the data may not be complete. The websites were searched during a spring semester when policies are likely stable, assuming new policies may be developed in the spring and summer but not implemented until the beginning of a fall semester. Consequently, any update being done on specific website pages should have been rather limited at that time. Additionally, when websites appeared to be unavailable or experiencing technical difficulties, the search was performed again at a different time. Lastly, the keyword search term list that was used was extensive, especially when the policies were not found in the "expected" locations.

Readers should be careful in drawing conclusions about the actual availability of child-related family policies for the universities presented in the study. The absence of a tenure clock extension policy from a university's website does not mean that a policy does not exist. The absence of the policy in this study merely signifies that such a policy was not available through a search of the website. But the argument can be made that a lack of finding the policy easily on the website is an indication that the university is not transparent with its information related to these events. That leads one to wonder whether an extension policy, if it does exist, is communicated internally well enough to be of value to those affected individuals and/or tenure and promotion committees. This is an avenue for future research.

Furthermore, organizational research has shown that formal policies may exist but not be adopted in the workplace, with employees being inconsistently informed of their benefits or being pressured to not use them. Institutional support for taking advantage of such policies may be associated with how transparent the institution is regarding family-friendly policies. This is another avenue for future researchers.

Future research questions include: How does faculty awareness regarding their own institution's policies on tenure clock extensions compare to the actual policy availability? Are tenure and promotion committees aware of these policies? How has the availability of these policies changed over time? Finally, what are faculty perceptions regarding the fairness of a variety of child-related friendly policy options? Substantial additional research and attention are warranted in the area of family-friendly policies in academic institutions as individuals move toward greater work-life balance and the recruiting supply of new faculty continues to dwindle.

\section{References}

American Association of University Professors. (2001). Statement of principles on family responsibilities and academic work. Retrieved from https://www.aaup.org/report/statement-principles-familyresponsibilities-and-academic-work

MCEACHARN, BOSWELL, CHAUHAN, \& SIEREVELD / DOI: 10.5929/9.2.4 
The Association to Advance Collegiate Schools of Business. (2015). Business school data guide. Retrieved from https://www.aacsb.edu/-/media/aacsb/publications/data-trends-booklet/2015.ashx

The Association of International Certified Professional Accountants. (2017). 2017 Trends in the supply of accounting graduates and the demand for public accounting recruits. Retrieved from https://www.aicpa.org/interestareas/accountingeducation/newsandpublications/downloadable documents/2017-trends-report.pdf

Antecol, H., Bedard, K., \& Stearns, J. (2018). Equal but inequitable: Who benefits from gender-neutral tenure clock stopping policies? American Economic Review, 108(9), 2420-41. doi: 10.1257/aer.20160613.

Baxter, J., \& Chesters, J. (2011). Perceptions of work-family balance: how effective are family-friendly policies? Australian Journal of Labour Economics. Centre for Labour Market Research, 14(2), 139.

Boyle, D. M., Carpenter, B. W., \& Hermanson, D. R. (2014). The accounting faculty shortage: Causes and contemporary solutions. Accounting Horizons. American Accounting Association, 29(2), 245-264.

Dahl, G. B., Løken, K. V., \& Mogstad, M. (2014). Peer effects in program participation.; American Economic Review. doi: 10.1257/aer.104.7.2049.

Fish, M., Becker, D. A., \& Miller, W. (2017). Meeting the Challenges posed by the shortage of accounting faculty: Customized recruiting strategies. Journal of Higher Education Management, 32(1), 115134.

Gunn, C. M., Freund, K. M., Kaplan, S. A., Raj, A., \& Carr, P. L. (2014). Knowledge and perceptions of family leave policies among female faculty in academic medicine. Women's Health Issues. Elsevier, 24(2), e205-e210.

Hunt, S. C. \& Jones, K. T. (2015). Recruitment and selection of accounting faculty in a difficult market. Global Perspectives on Accounting Education, 12, 23.

Jordan, C. E., Clark, S. J., \& Vann, C. E. (2008). Do gender differences exist in the publication productivity of accounting faculty?. Journal of Applied Business Research, 24(3), 77-85.

June, A. W. (2014). Fear of stigma lingers about use of family-friendly policies. Chronicle of Higher Education.

Juraqulova, Z. H., McCluskey, J. J., \& Mittelhammer, R. C. (2019). Work-life policies and female faculty representation in US doctoral-granting economics departments. Industrial Relations Journal. doi: 10.1111/irj.12246.

Kirby, E. \& Krone, K. (2002). "The Policy exists but you can't really use it": Communication and the structuration of work-family policies. Journal of Applied Communication Research, 30(1), 50-77.

Lazear, E. P. \& Rosen, S. (1990). Male-female wage differentials in job ladders. Journal of Labor Economics, 8(1), S106-S123. doi: 10.1086/298246.

Lester, J. \& Bers, T. (2011). Hiring and recruiting female faculty. Hiring the Next Generation of Faculty: New Directions for Community Colleges, 152, 41.

Martinez, L. R., O'Brien, K. R., \& Hebl, M. R. (2017). Fleeing the ivory tower: Gender differences in the turnover experiences of women faculty. Journal of Women's Health, 26(5), 580-586.

Plumlee, R. D. \& Reckers, P. M. J. (2014). Lessons not learned: Why is there still a crisis-level shortage of accounting Ph.D.s?. Accounting Horizons. doi: 10.2308/acch-50703.

MCEACHARN, BOSWELL, CHAUHAN, \& SIEREVELD / DOI: 10.5929/9.2.4 
Samble, J. N. (2008). Female faculty: Challenges and choices in the United States and beyond. New Directions for Higher Education, 2008(143), 55-62.

Su, X. \& Bozeman, B. (2016). Family friendly policies in STEM departments: Awareness and determinants. Research in Higher Education, 57(8), 990-1009.

Villablanca, A. C., Beckett, L., Nettiksimmons, J., \& Howell, L. P. (2011). Career flexibility and family-friendly policies: an NIH-funded study to enhance women's careers in biomedical sciences. Journal of Women's Health 20(10), 1485-1496.

Williams, J. (2002). Putting the AAUP's family-friendly policies into practice. The Chronicle of Higher Education, January 28.

About the Authors

Dr. Michelle McEacharn (mceacharn@ulm.edu) is a Professor of Accounting and the Susan and William Banowsky Endowed Chair in Accounting at The University of Louisiana Monroe. She also serves as the Program Coordinator. Her teaching interests include governmental/nonprofit accounting, mergers \& acquisitions, and international accounting. Her research interests include gender and work-life balance issues, nonprofit accounting topics, financial statements, and pedagogy. She also serves as Executive Director for the Federation of Business Disciplines, an interdisciplinary academic business conference group.

Katherine Boswell (boswell@ulm.edu) is an Associate Professor of Accounting and holds the Michelle McEacharn Endowed Professorship at the University of Louisiana Monroe. Her teaching interests include accounting systems (technology in accounting) and auditing. Her research interests include gender and work-life balance issues, auditing, sustainability reporting, and accounting systems issues. She also serves on the Board of Directors as Treasurer for a local not-for-profit.

Dr. Kriti Chauhan (chauhan@ulm.edu) is an Assistant Professor of Computer Information Systems at The University of Louisiana Monroe. She teaches information security, databases, management information systems, and information systems design. She has also taught introductory and advanced programming, and statistics as a Lecturer at University of Texas at Arlington. Her research interests include ethics, cybersecurity, social media, online word of mouth, and pedagogical methodology.

Sarah O'Connor Siereveld (siereveldso@warhawks.ulm.edu) is a Magna Cum Laude graduate of Syracuse University with a BFA in Musical Theatre. She currently serves as a Graduate Assistant at the University of the Louisiana at Monroe in the College of Business \& Social Sciences, where she is also pursuing her MBA. In her professional roles with Nespresso, Lululemon and Girl Scouts of Northern NJ she has created training curriculum and leadership development programs in both customer service and non-profit industries. Sarah's research interests include work-life balance issues and economic interests, including family business in the US and trade agreements. Other areas of expertise include grant writing for notfor-profits and experience as a professional actor throughout the US.

MCEACHARN, BOSWELL, CHAUHAN, \& SIEREVELD / DOI: 10.5929/9.2.4 